\title{
Population subdivision of saddled seabream Oblada melanura in the Aegean Sea revealed by genetic and morphometric analyses
}

\author{
G. A. Gkafas ${ }^{1}$, C. Tsigenopoulos ${ }^{2}$, A. Magoulas ${ }^{2}$, P. Panagiotaki ${ }^{1}$, D. Vafidis ${ }^{1}$, \\ Z. Mamuris ${ }^{3}$, A. Exadactylos ${ }^{1, *}$ \\ ${ }^{1}$ Department of Ichthyology and Aquatic Environment, School of Agricultural Sciences, University of Thessaly, Fytokou str., \\ 38446, Volos, Greece \\ ${ }^{2}$ Institute of Marine Biology and Genetics, Hellenic Centre of Marine Research, Heraklion, Crete 71003, Greece \\ ${ }^{3}$ Department of Biochemistry and Biotechnology, School of Health Sciences, University of Thessaly, 26 Ploutonos \& Aiolou str., \\ 41221, Larissa, Greece
}

\begin{abstract}
The population structure of marine fishes is often cryptic, due to limited knowledge about life history and ecological habitats. Understanding environmental stability is a challenge to retrieve possible structuring patterns responsible for dispersal and demographic habits. In the present study, a combination of genetic and phenotypic assessments was applied in order to investigate population structure of the saddled seabream Oblada melanura in the Aegean Sea, eastern Mediterranean basin. Analyses of 6 microsatellite loci and 15 morphometric characters revealed that saddled seabream individuals differ among northern, southern and central Aegean populations. These observed boundaries may be related to the differentiated seascape of the Aegean Sea, suggesting that oceanographic factors are a significant stressor for population subdivision of the saddled seabream. Individual-based landscape genetic approaches and multivariate analysis of the morphometric characters suggest the presence of habitat-related limitations of saddled seabream dispersal potential. Molecular genetics and phenotypic analyses along with life-history traits provide useful informative data for the management and conservation schemes applied for this species in the Aegean Sea.
\end{abstract}

KEY WORDS: Oblada melanura $\cdot$ Microsatellite $\cdot$ Morphometrics $\cdot$ Aegean Sea $\cdot$ Population structure

\section{INTRODUCTION}

The marine environment forms a continuous water body that does not exhibit clear barriers. Although, due to a lack of barriers, homogeneity is expected in marine species that have a large geographic range and high dispersal, a fine-scale population structure is often reported for these species (Bekkevold et al. 2005, Jørgensen et al. 2005, Hoelzel et al. 2007, Hoelzel 2009, Kelly \& Palumbi 2010, Pilot et al. 2010).

Significant genetic differentiation has been reported for marine fishes, the extent of which varies among species (Arculeo et al. 2003, Pinera et al. 2007, Zulliger et al. 2009, González-Wangüemert et al. 2011). Structural patterns are not always correlated with geographic components, but are the result of complex demographic stochasticity, such as local resources, social coherence and environmental stability (Galarza et al. 2009, McCusker \& Bentzen 2010, Salmenkova 2011). Despite the fact that oceanographic features, such as water temperature, salinity and oxygen level, are known to play a key role in species habitats, the mechanisms driving the dispersal and population structure of marine fishes remain unclear. 
The Mediterranean Sea is a closed basin ecosystem, with a relative high temperature and different seasonal rainfall patterns and flow dynamics underlying a highly oligotrophic area (Siokou-Frangou et al. 2002). Spatial and temporal genetic population structure studies in the Mediterranean Sea report differentiation between the eastern and western part of the basin (Viñas et al. 2004, Rolland et al. 2007, Coll et al. 2010), possibly due to historical demographic processes but also due to hydrological and ecological traits (e.g. Magoulas et al. 2006). The majority of these studies have focused on fish stock exploitation through the population structure of the species in question, revealing patterns via life-history traits and biogeographic barriers. Variations in oceanographic features play a key role in the life history of such species, most obviously on larval dispersal due to food availability. Species with no pelagic larval dispersal tend to evolve as highly subdivided populations, suggesting low gene flow between them (Palumbi 1994), whereas species with longer pelagic larval duration are expected to present higher gene flow values and lower population differentiation (Bohonak 1999).

The saddled seabream Oblada melanura L. belongs to the family Sparidae and occurs in the Mediterranean Sea, eastern Atlantic, Biscay Bay and from the Strait of Gibraltar to Angola. It is also recorded in Madeira, Cape Verde and the Canary Islands (Bauchot \& Hureau 1986, Bauchot et al. 1981). It is a gregarious species, living in coastal regions, on rocky and seaweed (Posidonia oceanica) beds up to $30 \mathrm{~m}$ deep, creating small schools near the coastline. During the day it hides in small crevices and cavities of rocky beds (Bauchot \& Hureau 1990). It is an omnivorous species, preying on small invertebrates and phytoplankton (Klaoudatos et al. 1997, Lenfant \& Olive 1998). In the Mediterranean Sea spawning is from April to June (Bauchot \& Hureau 1986) and, according to Jardas (1996), in the Adriatic Sea in late summer. The saddled seabream is of high economic importance in the Mediterranean Sea, as it is a species of interest not only for fisheries but also for tourists (i.e. angling). It is one of the species that is targeted to be set in aquaculture enterprises (Klaoudatos et al. 1997), as are many others members of the Sparidae family.

To evaluate the effectiveness of biodiversity management programs detailed knowledge of the population ecology of the managed species is necessary. Recent information on the stock definition of sparids, in particular saddled seabream, is scarce, although they are commercially and ecologically important fish in the Mediterranean Sea. Genetic and abundance data, in conjunction with morphometric assessments, may provide important information on saddled seabream stock composition, the evolutionary mechanisms related to specific demographic patterns in the Mediterranean Sea and the effect of selective environmental pressures.

It is hypothesized that variation in food availability and abundance affect the density and dispersal of saddled seabream in the Mediterranean, and therefore, its population structure should correlate with oceanographic characteristics that cause such variation. To test such a hypothesis, the genetic structure of saddled seabream was analyzed and correlated to seascape characteristics. The Aegean Sea (eastern Mediterranean basin) is a complex ecosystem with a highly irregular coastline and semi-isolated deep basins (Olson et al. 2007), and presents a novel challenge as a transition between the eutrophic Black Sea and the oligotrophic Mediterranean basin. Six microsatellite loci were analysed to evaluate genetic polymorphism in the Aegean Sea using a combination of recent individual-based landscape genetic approaches.

Additionally, 15 morphological assessments were used to determine the geographical variation of the given stocks. Multivariate statistical analysis of morphometric characters has provided useful results in the past for assessing stock structure of several marine fish species (Schaefer 1989), however, the use of morphological characteristics does have some limitations - they are polygenically inherited, have low heritability and are subject to considerable environmental plasticity (Karakousis et al. 1991). Multivariate analysis of a set of phenotypic characters is regarded as a more appropriate method than the use of a single character for determining relationships between populations of a given species (Thorpe 1987, Palma \& Andrade 2004).

\section{MATERIALS AND METHODS}

\section{Sample collection and study area}

Adult saddled seabream individuals were collected as bycatch from 8 locations in the Aegean Sea. Sampling sites and sizes along with main oceanographic features are shown in Fig. 1. The total sample size was 514 individuals; sampling was carried out by local fishermen using gillnets. A small amount of muscle tissue was obtained and stored in $70 \%$ ethanol for further analysis. 


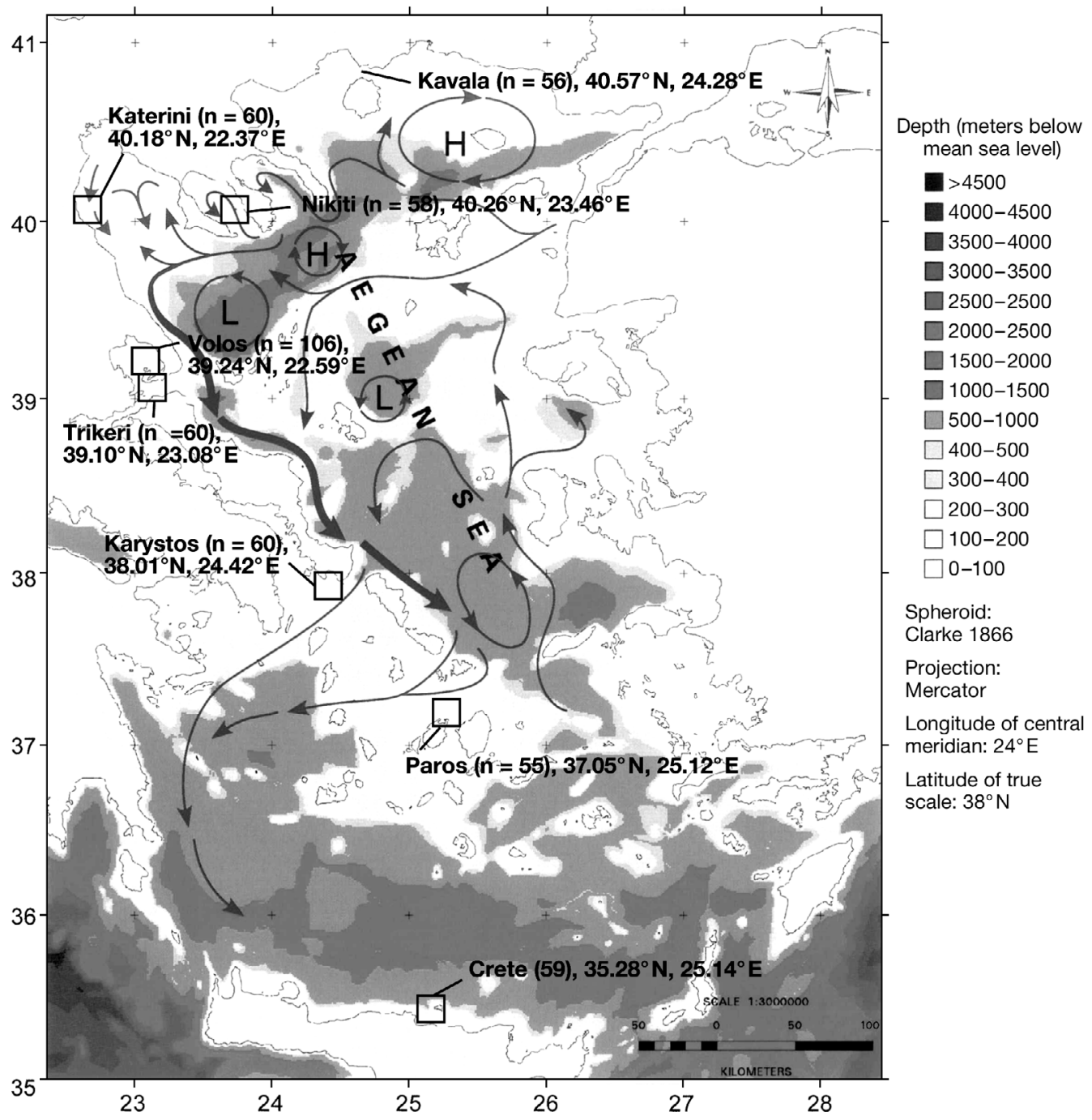

Fig. 1. Oblada melanura. Oceanographic features (current patterns are illustrated with arrows), sample sites and number of saddled seabream specimens (n) in the Aegean Sea (after Olson et al. 2007)

\section{DNA extraction and PCR amplification}

DNA was extracted from $0.01 \mathrm{~g}$ of muscle tissue following the standard phenol/chloroform protocol (Sambrook \& Russel 2001). DNA was preserved in $10 \mathrm{mM}$ TE and stored in $-20^{\circ} \mathrm{C}$. A panel of 6 microsatellites was tested and optimized for the genetic analysis: SAI10, SAI12, SAI19 (Brown et al. 2005) and Pma1, Pma2 and GA2A (Adcock et al. 2000). Roques et al. (2007) characterized an additional panel of species-specific microsatellites which ought to be under future consideration for screening. The total volume of the PCR reaction was $10 \mu \mathrm{l}$; consisting of $40 \mathrm{ng}$ of template DNA, 10X Buffer, $1.5 \mathrm{mM} \mathrm{MgCl}_{2}, 0.2 \mathrm{mM}$ dNTPs, 1 U Taq polymerase (all Invitrogen) and $0.5 \mu \mathrm{M}$ of each primer (Operon-Invitrogen). The florescence primers used were labelled by 4 different dyes: FAM,
HEX, ROX and TAMRA (Invitrogen). The PCR conditions were as follows: $95^{\circ} \mathrm{C}$ for $3 \mathrm{~min}$, followed by 30 cycles of $1 \mathrm{~min}$ at $95^{\circ} \mathrm{C}, 50 \mathrm{~s}$ at $\mathrm{T}^{\circ} \mathrm{C}$ annealing of the primer set, and $30 \mathrm{~s}$ at $72^{\circ} \mathrm{C}$, with a final step of $15 \mathrm{~min}$ at $72^{\circ} \mathrm{C}$. PCR products were verified by $1 \%$ agarose gel electrophoresis (Invitrogen). Fluorescently labelled PCR products were run on an ABI 3700 automated sequencer (Applied Biosystems). Each specimen's alleles were scored by STRand software v.2.0 (Toonen \& Hughes 2001) and 10\% of genotypes were rerun for error checking.

\section{Genetic analysis}

All loci were tested for the presence of null alleles or allelic dropout using the software MICRO- 
CHECKER v.2.2.3 (van Oosterhout et al. 2004). Exact tests for Hardy-Weinberg equilibrium (HWE), linkage disequilibrium (LD, using Fisher's exact tests), expected heterozygosity $\left(H_{\mathrm{EXP}}\right)$ and observed heterozygosity $\left(H_{\mathrm{OBS}}\right)$ were carried out using the software Genepop v.3.4 (Raymond \& Rousset 1995). $F_{\mathrm{ST}}$ and $F_{\text {IS }}$ indices (using the formulation described by Weir \& Cockerham 1984) and number of alleles per locus were calculated using FSTAT v.2.9.3.2 software (Goudet 2001). This software was also used to calculate the allelic richness (rarefaction) per locus and per population. A Bonferroni correction was carried out for each pairwise analysis (Rice 1989). A recalculation was made in order to estimate null and visible allele frequencies for each locus and population; for such estimations, the ENA method was used as described in Chapuis \& Estoup (2007). The ENA correction method was found to efficiently correct the positive bias induced by the presence of null alleles on $F_{\mathrm{ST}}$ estimation and provide a more accurate estimation of $F_{\mathrm{ST}}$. To evaluate hypothesized patterns of spatial genetic structure, a hierarchical analysis of molecular variance (AMOVA) (Excoffier \& Lischer 2010) was performed using Arlequin 3.5 software in order to partition variance components attributable to (1) variance between areas; (2) variance between populations within areas; and (3) variance among samples within populations. The significance of the resulting $F$-indices and variance components were permutated 10000 times using the Bonferroni correction (Rice 1989).

Population structure was assessed using the software STRUCTURE v.2.3 (Pritchard et al. 2000a), where identified migrants and admixed individuals were assigned. The Correlated Allele Frequency Model (Falush et al. 2003b) records the allele frequencies in a hypothetical 'ancestral' population without specifying geographic area as a prior. To test the convergence of the priors and the appropriateness of the chosen burn-in length and simulation length, 3 independent repeats were run for each value of $K$, the number of clusters $(2 \leq K \leq 10)$. Burn-in length and length of simulation were set at 500000 and 1000000 repetitions, respectively. Isolation by distance software (IBD) was used to assess whether the association between genetic similarity $\left(F_{\mathrm{ST}} /\left[1-F_{\mathrm{ST}}\right]\right.$; Rousset 1997) and geographic distance is statistically significant using a Mantel test based on 1000 randomizations (Bohonak 2002). The software uses partial correlation coefficients between genetic and geographical distances. We tested for evidence of recent bottleneck events using the software BOTTLENECK v.1.2.02 (Piry et al. 1999) and the Stepwise Mutation
Model (SMM). A one-tailed Wilcoxon singed rank test was used to determine numbers of loci in heterozygosity excess. The mode shift indicator tested the allele frequency distribution that discriminates bottlenecked populations from stable populations (Luikart et al. 1998).

The software Barrier v.2.2 (Manni et al. 2004) was utilized in order to identify locations and the directions of barriers using a computational geometry approach. The Monmonier (1973) maximum difference algorithm provided a more realistic representation of the barriers in a genetic landscape and a significance test was implemented by means of bootstrap matrix analysis. In order to obtain a geometric satisfactory map from a list of geographic $x, y$ coordinates, a Voronoï tessellation (Voronoï 1908) calculator was used. Out of this tessellation a Delaunay triangulation (Brassel \& Reif 1979) was obtained. Additionally, Migrate v.3.3.2 (Beerli \& Palczewski 2010) was implemented in order to reveal any directionality of the migration patterns.

\section{Morphometric analysis}

Fifteen morphometric characters were measured on each specimen according to Hubbs \& Lagler (1967). These morphometric characters were: standard length, maximum body depth, minimum body depth, caudal peduncle length, head length, diameter of eye, preorbital distance, postorbital distance, predorsal fin distance, dorsal fin height, dorsal fin base length, anal fin height, anal fin base length, pectoral fin length and wet weight (Fig. 2). All measurements were taken to the nearest $0.1 \mathrm{~mm}$ or $\mathrm{mg}$.

Parameters such as sampling timing, sexual dimorphism, allometric growth, sampling more than one population in each water body, different phenotypic groups within the sample, and maturation stage of the fish could impose some limitations on a study (Roughgarden 1972, 1974). The effect of allometry and sexual dimorphism was minimized after the transformation of the original measurements. In order to overcome the fourth parameter (sampling more than one population in each water body) sampling was restricted to as small a geographic area as possible. As for maturation stage, every effort was made to choose only mature fish for the analysis. To minimize any variation resulting from allometric growth, all morphometric measurements were standardized according to:

$$
e=\log Y-b\left(\log X-\log X_{1}\right)
$$




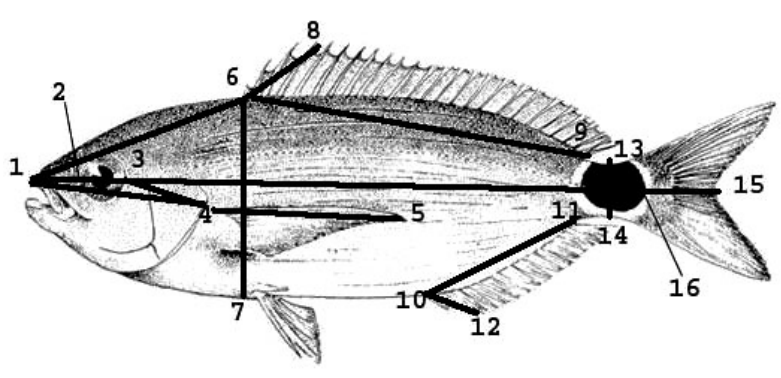

Fig. 2. Oblada melanura. Morphometric measurements: 1-2: Preorbital distance; 2-3: diameter of eye; 3-4: postorbital distance; 1-4: head length; 4-5: pectoral fin length; 1-6: predorsal fin distance; 6-8: dorsal fin height; 6-9: dorsal fin base length; 6-7: maximum body depth; 10-11: anal fin base length; 10-12: anal fin height; 13-14: minimum body depth; 11-16: caudal peduncle length; 1-15: standard length

where $e$ is a standardized measurement, $Y$ is character length, $b$ is the slope of $\log Y$ against $\log X$ plot of each population, $X$ is the standardized length of the specimen and $X_{1}$ is the mean standard length of the specimen examined. According to Reist (1985), this transformation best reflects shape variation among groups independently of size factor. Therefore, total length and standard lengths of each specimen were excluded from the final analysis.

Principal component analysis (PCA) was used to test for the contribution of the remaining 13 morphological characters in the configuration of variance. Forward stepwise discriminant analysis (DA) based on the generalized Mahalanobis distance was used to determine the similarity between populations and the ability of these characters to identify the specimens correctly. The above analysis was performed using SPSS v.15.0 statistical software.

\section{RESULTS}

A moderately high level of polymorphism was detected in all tested loci, ranging from 18 alleles at the Pma1 locus to 93 alleles at the SAI19 locus. However, all loci showed evidence of the presence of null alleles. These 6 loci also showed departures from HWE ( $p<0.01$ ). Observed heterozygosity values were quite low across all loci for all populations (mean $H_{\mathrm{OBS}}=0.597$ ) and were comparatively lower than overall expected heterozygosity values (mean $\left.H_{\text {EXP }}=0.898\right)$. Values of $H_{\mathrm{OBS}}, H_{\mathrm{EXP}}, F_{\mathrm{IS}}$ and allelic richness, as well as the numbers of alleles are shown in Table 1.

$F_{\text {ST }}$ values between the 8 sampled geographical areas of the saddled seabream ranged from 0.007 between Volos and Karystos to 0.1162 between Paros and Karystos (Table 2). Most of the values were highly significant after Bonferroni correction (Rice 1989). Pairwise $F_{\mathrm{ST}}$ values and their significances did not differ from the original pattern, even when recalculated using the ENA method (see Table 2). A hierarchical analysis (AMOVA) of the genetic structure showed that the proportion of total genetic variation that can be ascribed to differentiation between the southern, central and northern Aegean areas $\left(F_{\mathrm{CT}}\right)$ is close to zero (Table 3). Furthermore, genetic structuring appears to take place among populations within each area $\left(F_{\mathrm{SC}}=0.042\right)$ and within populations $\left(F_{\mathrm{ST}}=\right.$ 0.322). Approximately $82 \%$ of the total genetic variation was due to variation within populations and $11 \%$ was due to variation among populations within the 3 areas. A Bayesian individual assignment implemented in STRUCTURE is shown in Fig. 3, without using geographical area as a prior. The highest posterior probability was for $K=4$ and $\ln (\mathrm{PD})=$ -7866.6 (Fig. 4). The Wilcoxon sign-ranked test under the SMM model, implemented in BOTTLENECK, revealed no deviance from the mutation-drift equilibrium overall (data not shown). Furthermore, the implemented IBD model of geographical and genetic distances was insignificant.

The geometric map, using Barrier software, illustrated 4 barriers (Fig. 5). The first barrier separates the Crete and Paros populations from the Karystos population, the second separates the Karystos population from the Volos and Trikeri populations, the third separates the Volos and Trikeri populations from the Katerini and Nikiti populations, and the fourth determines a barrier to gene flow between the Katerini, Nikiti and Kavala populations. Analysis using Migrate software did not reveal any migration directionality. The connection type matrix pinpointed that migration rates were free to vary, without any clear direction of the migrants (data not shown).

Moreover, univariate ANOVA carried out on the transformed data (Zar 1984) indicated significant differences between the 8 populations for all morphometric characters except maximum body depth and anal fin base length $\left(F_{212,0.05}=3.23, \mathrm{p} \ll 0.05\right)$. The PCA extracted 3 factors with eigenvalues $>0.75$, explaining $70.6 \%$ of the variance (Table 4 ).

The characters of primary importance in distinguishing between the groups were head length for the first canonical variable and dorsal fin height for the second. Using these morphometric characters, each specimen could be classified (using DA) correctly to the 8 populations with an accuracy of $66.5 \%$ (Table 5, Fig. 6). 
Table 1. Oblada melanura. Genetic variation at each locus for each population of saddled seabream in the southern, central and northern Aegean Sea. $H_{\mathrm{OBS}}$ : observed heterozygosity; $H_{\mathrm{EXP}}$ : expected heterozygosity; $F_{\mathrm{IS}}$ : inbreeding index. ${ }^{* *} \mathrm{p}<0.01$

\begin{tabular}{|c|c|c|c|c|c|c|c|c|c|}
\hline Locus & Parameter & Volos & Trikeri & Kavala & Katerini & Karystos & Nikiti & Paros & Crete \\
\hline SAI10 & $\begin{array}{l}H_{\mathrm{OBS}} \\
H_{\mathrm{EXP}} \\
\text { Allelic richness } \\
F_{\mathrm{IS}} \\
\text { No. of alleles }\end{array}$ & $\begin{array}{l}0.697 \\
0.963 \\
7.053 \\
0.277^{* *} \\
\quad 45\end{array}$ & $\begin{array}{l}0.5 \\
0.938 \\
6.430 \\
0.474^{* *} \\
\quad 13\end{array}$ & $\begin{array}{l}0.5 \\
0.936 \\
6.436 \\
0.471^{* *} \\
\quad 19\end{array}$ & $\begin{array}{l}0.611 \\
0.96 \\
6.965 \\
0.37^{* *} \\
\quad 10\end{array}$ & $\begin{array}{l}0.5 \\
0.868 \\
5.600 \\
0.498^{* *} \\
\quad 15\end{array}$ & $\begin{array}{l}0.529 \\
0.927 \\
6.270 \\
0.436^{* *} \\
\quad 8\end{array}$ & $\begin{array}{l}1 \\
1 \\
8 \\
0 \\
11\end{array}$ & $\begin{array}{l}0.778 \\
0.928 \\
6.279 \\
0.17 \\
15\end{array}$ \\
\hline SAI12 & $\begin{array}{l}H_{\mathrm{OBS}} \\
H_{\mathrm{EXP}} \\
\text { Allelic richness } \\
F_{\mathrm{IS}} \\
\text { No. of alleles }\end{array}$ & $\begin{array}{l}0.598 \\
0.957 \\
6.912 \\
0.376^{* *} \\
\quad 41\end{array}$ & $\begin{array}{l}0.6 \\
0.954 \\
6.795 \\
0.377^{* *} \\
\quad 16\end{array}$ & $\begin{array}{l}0.688 \\
0.901 \\
6.024 \\
0.243^{* *} \\
\quad 20\end{array}$ & $\begin{array}{l}0.5 \\
0.954 \\
6.849 \\
0.482^{* *} \\
\quad 13\end{array}$ & $\begin{array}{l}0.6 \\
0.953 \\
6.772 \\
0.383^{* *} \\
\quad 17\end{array}$ & $\begin{array}{l}0.611 \\
0.951 \\
6.749 \\
0.364^{* *} \\
\quad 8\end{array}$ & $\begin{array}{l}0.8 \\
0.933 \\
6.6 \\
0.158^{* *} \\
14\end{array}$ & $\begin{array}{l}0.889 \\
0.967 \\
7.077 \\
0.086 \\
15\end{array}$ \\
\hline SAI19 & $\begin{array}{l}H_{\mathrm{OBS}} \\
H_{\mathrm{EXP}} \\
\text { Allelic richness } \\
F_{\mathrm{IS}} \\
\text { No. of alleles }\end{array}$ & $\begin{array}{l}0.708 \\
0.973 \\
7.303 \\
0.273^{* *} \\
\quad 58\end{array}$ & $\begin{array}{l}0.6 \\
0.933 \\
6.345 \\
0.363^{* *} \\
\quad 13\end{array}$ & $\begin{array}{l}0.5 \\
0.929 \\
6.369 \\
0.47^{* *} \\
\quad 23\end{array}$ & $\begin{array}{l}0.842 \\
0.959 \\
6.982 \\
0.125^{* *} \\
\quad 15\end{array}$ & $\begin{array}{l}0.7 \\
0.974 \\
7.263 \\
0.292^{* *} \\
\quad 21\end{array}$ & $\begin{array}{l}0.765 \\
0.963 \\
7.042 \\
0.211^{* *} \\
\quad 8\end{array}$ & $\begin{array}{l}0.8 \\
0.956 \\
6.756 \\
0.179^{* *} \\
13\end{array}$ & $\begin{array}{l}0.667 \\
0.954 \\
6.923 \\
0.314^{* *} \\
16\end{array}$ \\
\hline Pma1 & $\begin{array}{l}H_{\mathrm{OBS}} \\
H_{\mathrm{EXP}} \\
\text { Allelic richness } \\
F_{\mathrm{IS}} \\
\text { No. of alleles }\end{array}$ & $\begin{array}{l}0.467 \\
0.788 \\
4.397 \\
0.408^{* *} \\
\quad 13\end{array}$ & $\begin{array}{l}0.556 \\
0.883 \\
5.415 \\
0.377^{* *} \\
\quad 9\end{array}$ & $\begin{array}{l}0.438 \\
0.704 \\
3.542 \\
0.386^{* *} \\
\quad 5\end{array}$ & $\begin{array}{l}0.222 \\
0.654 \\
3.511 \\
0.667^{* *} \\
\quad 4\end{array}$ & $\begin{array}{l}0.4 \\
0.7 \\
3.273 \\
0.442^{* *} \\
\quad \quad \quad 8\end{array}$ & $\begin{array}{l}0.412 \\
0.797 \\
4.471 \\
0.491^{* *} \\
\quad 3\end{array}$ & $\begin{array}{l}0.2 \\
0.511 \\
2.778 \\
0.636^{* *} \\
\quad 5\end{array}$ & $\begin{array}{l}0.125 \\
0.792 \\
3.664 \\
0.851^{* *} \\
\quad 6\end{array}$ \\
\hline Pma2 & $\begin{array}{l}H_{\mathrm{OBS}} \\
H_{\mathrm{EXP}} \\
\text { Allelic richness } \\
F_{\mathrm{IS}} \\
\text { No of alleles }\end{array}$ & $\begin{array}{l}0.614 \\
0.935 \\
6.48 \\
0.344^{* *} \\
\quad 35\end{array}$ & $\begin{array}{l}0.9 \\
0.964 \\
7.039 \\
0.068^{* *} \\
\quad 18\end{array}$ & $\begin{array}{l}0.563 \\
0.944 \\
6.579 \\
0.412^{* *} \\
\quad 20\end{array}$ & $\begin{array}{l}0.684 \\
0.963 \\
7.029 \\
0.295^{* *} \\
\quad 13\end{array}$ & $\begin{array}{l}0.8 \\
0.942 \\
6.61 \\
0.158^{* *} \\
\quad 20\end{array}$ & $\begin{array}{l}0.833 \\
0.96 \\
6.985 \\
0.135^{* *} \\
\quad 6\end{array}$ & $\begin{array}{l}0.4 \\
0.844 \\
5.178 \\
0.556^{* *} \\
12\end{array}$ & $\begin{array}{l}0.778 \\
0.948 \\
8 \\
0.188^{* *} \\
15\end{array}$ \\
\hline GA2A & $\begin{array}{l}H_{\mathrm{OBS}} \\
H_{\mathrm{EXP}} \\
\text { Allelic richness } \\
F_{\mathrm{IS}} \\
\text { No of alleles }\end{array}$ & $\begin{array}{l}0.516 \\
0.917 \\
6.089 \\
0.438^{* *} \\
\quad 22\end{array}$ & $\begin{array}{c}1 \\
0.921 \\
6.069 \\
-0.089 \\
11\end{array}$ & $\begin{array}{l}0.5 \\
0.911 \\
5.927 \\
0.459^{* *} \\
\quad 9\end{array}$ & $\begin{array}{l}0.579 \\
0.861 \\
5.182 \\
0.333^{* *} \\
\quad 9\end{array}$ & $\begin{array}{l}0.6 \\
0.921 \\
5.986 \\
0.361^{* *} \\
\quad 13\end{array}$ & $\begin{array}{l}0.556 \\
0.886 \\
5.608 \\
0.38^{* *} \\
5\end{array}$ & $\begin{array}{l}0.2 \\
0.867 \\
4.733 \\
0.789^{* *} \\
\quad 5\end{array}$ & $\begin{array}{l}0.333 \\
0.791 \\
3.505 \\
0.593^{* *} \\
12\end{array}$ \\
\hline Total & $\begin{array}{l}H_{\mathrm{OBS}} \\
H_{\mathrm{EXP}} \\
\text { Allelic richness } \\
F_{\mathrm{IS}}\end{array}$ & $\begin{array}{l}0.600 \\
0.922 \\
6.372 \\
0.353^{* *}\end{array}$ & $\begin{array}{l}0.693 \\
0.932 \\
6.349 \\
0.262^{* *}\end{array}$ & $\begin{array}{l}0.532 \\
0.888 \\
5.813 \\
0.407^{* *}\end{array}$ & $\begin{array}{l}0.573 \\
0.892 \\
6.086 \\
0.379^{* *}\end{array}$ & $\begin{array}{l}0.600 \\
0.893 \\
5.917 \\
0.356^{* *}\end{array}$ & $\begin{array}{l}0.618 \\
0.914 \\
6.188 \\
0.336^{* *}\end{array}$ & $\begin{array}{l}0.567 \\
0.852 \\
5.674 \\
0.386^{* *}\end{array}$ & $\begin{array}{l}0.595 \\
0.897 \\
5.990 \\
0.367^{* *}\end{array}$ \\
\hline
\end{tabular}

Table 2. Oblada melanura. $F_{\mathrm{ST}}$ values between the 8 sampled geographical areas of saddled seabream (ns: non-significant, ${ }^{* *} \mathrm{p}<0.01,{ }^{* * *} \mathrm{p}<0.001$, after Bonferroni correction). Values in parentheses are the recalculated $F_{\mathrm{ST}}$ values after application of the ENA method

\begin{tabular}{|c|c|c|c|c|c|c|c|c|}
\hline & Volos & Trikeri & Kavala & Katerini & Karystos & Nikiti & Paros & Crete \\
\hline Volos & - & & & & & & & \\
\hline Trikeri & $\begin{array}{c}0.02527^{* * *} \\
\left(0.021^{* * *}\right)\end{array}$ & - & & & & & & \\
\hline Kavala & $\begin{array}{c}0.01270^{\mathrm{ns}} \\
\left(0.012^{\mathrm{ns}}\right)\end{array}$ & $\begin{array}{c}0.04246^{* * *} \\
\left(0.032^{* * *}\right)\end{array}$ & - & & & & & \\
\hline Katerini & $\begin{array}{c}0.07151^{* * *} \\
\left(0.06^{* * *}\right)\end{array}$ & $\begin{array}{l}0.04333^{* * *} \\
\left(0.0321^{* * *}\right)\end{array}$ & $\begin{array}{c}0.09333^{* * *} \\
\left(0.088^{* * *}\right)\end{array}$ & - & & & & \\
\hline Karystos & $\begin{array}{c}0.00704^{\mathrm{ns}} \\
\left(0.003^{\mathrm{ns}}\right)\end{array}$ & $\begin{array}{c}0.04205^{* * *} \\
\left(0.031^{* * *}\right)\end{array}$ & $\begin{array}{c}0.00875^{\mathrm{ns}} \\
\left(0.005^{\mathrm{ns}}\right)\end{array}$ & $\begin{array}{c}0.09069^{* * *} \\
\left(0.089^{* * *}\right)\end{array}$ & - & & & \\
\hline Nikiti & $\begin{array}{c}0.06357^{* * *} \\
\left(0.051^{* * *}\right)\end{array}$ & $\begin{array}{c}0.03426^{* * *} \\
\left(0.023^{* * *}\right)\end{array}$ & $\begin{array}{c}0.08249^{* * *} \\
\left(0.074^{* * *}\right)\end{array}$ & $\begin{array}{c}0.01131^{\mathrm{ns}} \\
\left(0.008^{\mathrm{ns}}\right)\end{array}$ & $\begin{array}{c}0.08088^{* * *} \\
\left(0.73^{* * *}\right)\end{array}$ & - & & \\
\hline Paros & $\begin{array}{c}0.09476^{* * *} \\
\left(0.082^{* * *}\right)\end{array}$ & $\begin{array}{c}0.04993^{\mathrm{ns}} \\
\left(0.031^{\mathrm{ns}}\right)\end{array}$ & $\begin{array}{c}0.11406^{* * *} \\
\left(0.095^{* * *}\right)\end{array}$ & $\begin{array}{l}0.01539^{n s} \\
\left(0.009^{n s}\right)\end{array}$ & $\begin{array}{c}0.11622^{* * *} \\
\left(0.109^{* * *}\right)\end{array}$ & $\begin{array}{c}0.03062^{\mathrm{ns}} \\
\left(0.016^{\mathrm{ns}}\right)\end{array}$ & - & \\
\hline Crete & $\begin{array}{c}0.07369^{* * *} \\
\left(0.065^{* * *}\right)\end{array}$ & $\begin{array}{c}0.05079^{* *} \\
\left(0.045^{* *}\right)\end{array}$ & $\begin{array}{c}0.08885^{* * *} \\
\left(0.081^{* * *}\right)\end{array}$ & $\begin{array}{c}0.02221^{\mathrm{ns}} \\
\left(0.015^{\mathrm{ns}}\right)\end{array}$ & $\begin{array}{l}0.08365^{* * *} \\
\left(0.0712^{* * *}\right)\end{array}$ & $\begin{array}{c}0.01958^{\mathrm{ns}} \\
\left(0.011^{\mathrm{ns}}\right)\end{array}$ & $\begin{array}{c}0.03425^{\mathrm{ns}} \\
\left(0.02^{\mathrm{ns}}\right)\end{array}$ & - \\
\hline
\end{tabular}




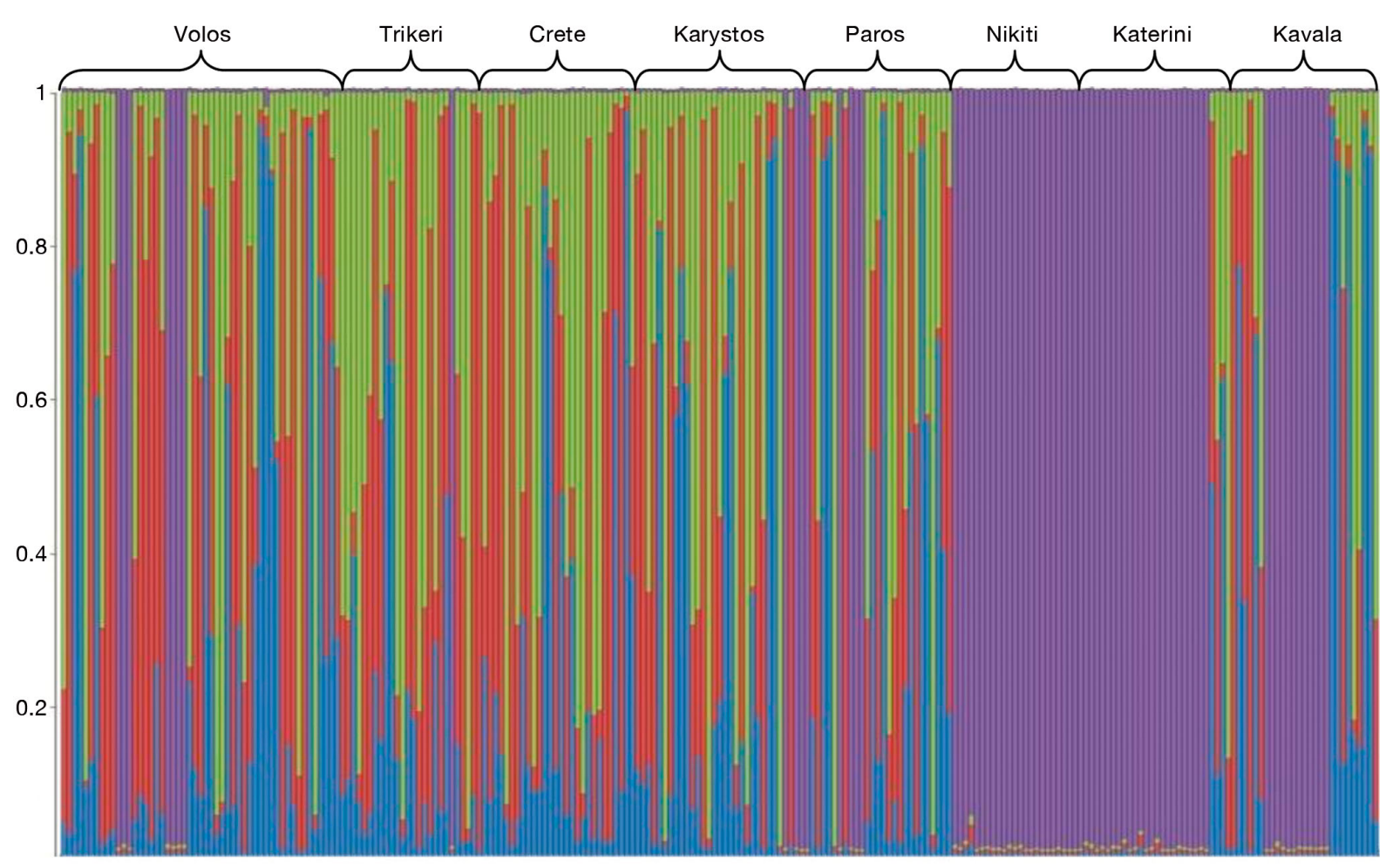

Fig. 3. Oblada melanura. Bayesian individual assignment implemented in STRUCTURE for $K=4$ clusters without using geographical area as a prior. The $y$-axis represents the probability of assignment of an individual to each cluster and each color corresponds to the suggested cluster

Table 3. Oblada melanura. AMOVA of grouped into 3 areas: northern, central and southern Aegean Sea. ns: non-significant, ${ }^{* * *} \mathrm{p}<0.001$

\begin{tabular}{|lrrrcc|}
\hline & df & $\begin{array}{c}\text { Variance } \\
\text { component }\end{array}$ & SS & $\begin{array}{c}\text { Variance } \\
\text { explained (\%) }\end{array}$ & Fixation index \\
\hline Between areas & 2 & 19.054 & -0.00623 & 11.2 & $F_{\mathrm{CT}}=-0.00233^{\text {ns }}$ \\
Among populations & 5 & 36.388 & 0.11322 & 25.5 & $F_{\mathrm{SC}}=0.04227^{* * *}$ \\
$\begin{array}{l}\text { within areas } \\
\text { Within populations }\end{array}$ & 217 & 735.800 & 0.82539 & 63.3 & $F_{\mathrm{ST}}=0.32174^{* * *}$ \\
\hline
\end{tabular}

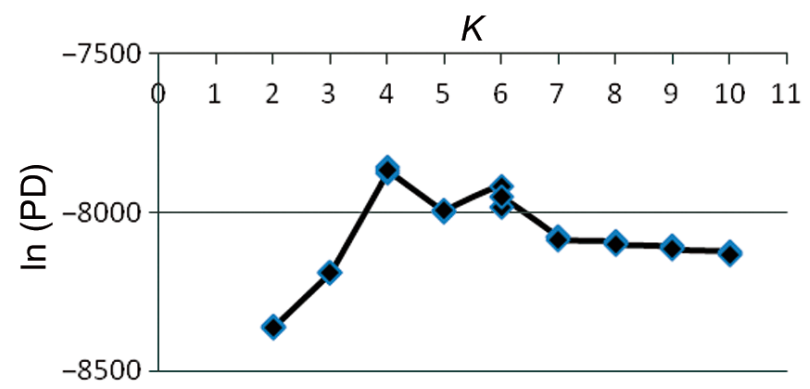

Fig. 4. Oblada melanura. Determination of the number of clusters $(K)$ including all 3 repetitions for each $K$ without geographical area as a prior. The highest peak denotes the most likely number of clusters according to the Pritchard Bayes formula. PD: probability of data

\section{DISCUSSION}

The genetic individual-based approaches show that most of the saddled seabream in the central and south Aegean Sea form a relatively continuous population, despite a complex coastline in the area. However, the significant and relatively high $F_{\mathrm{ST}}$ values between central Aegean populations (Volos, Trikeri, Karystos) and south Aegean populations (Paros, Crete) revealed a subdivision of the species. The striking result of the relatively low but significant level, in some cases, of genetic differentiation between the northern Aegean group of populations and the group of central and south Aegean populations illustrates a potential small-scale population structure in the targeted area for the species in question. The Bayesian individual assignment proposes a differentiation between the northern grouping of specimens and the rest of the study area. However, the geometric map analysis revealed barriers to gene flow between the south and central Aegean and between the central and north Aegean Sea. 


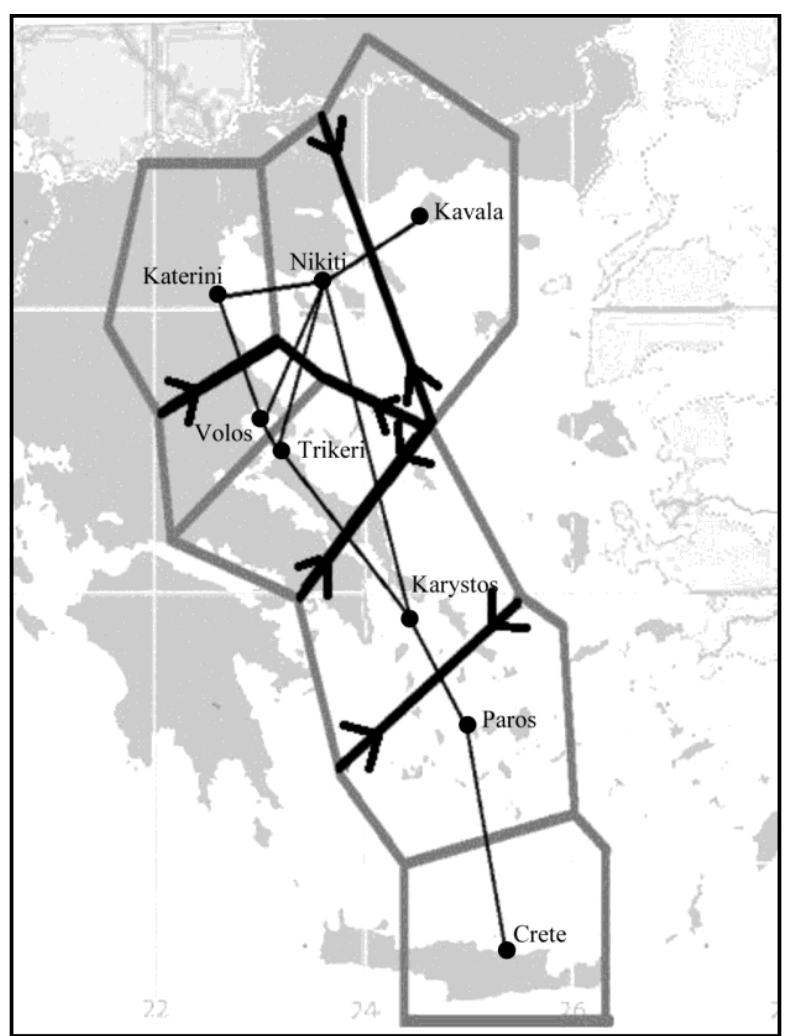

Fig. 5. Oblada melanura. Voronoï tessellation (in grey) of the points (populations) according to geographical locations (black circles) and the corresponding Delaunay triangulation (in dark grey). The bold black lines with arrows indicate the 4 barriers. Dotted lines represent biogeographic subareas of the Aegean Sea (after Voultsiadou 2005b)

Table 4. Oblada melanura. Results of principal component analysis (PCA) and factor loadings for each morphometric variable on the 3 extracted PCA factors after varimax normalized rotation

\begin{tabular}{|lrrr|}
\hline Factor & Eigenvalue & $\begin{array}{c}\% \text { of } \\
\text { variance }\end{array}$ & $\begin{array}{c}\text { Cumulative } \\
\%\end{array}$ \\
\hline 1 & 7.237 & 55.671 & 55.671 \\
2 & 1.194 & 9.187 & 64.857 \\
3 & 0.746 & 5.738 & 70.595 \\
Character & Factor 1 & Factor 2 & Factor 3 \\
\hline Maximum body depth & 0.868 & -0.145 & 0.019 \\
Minimum body depth & 0.767 & -0.138 & -0.260 \\
Caudal peduncle length & 0.724 & -0.024 & 0.318 \\
Head length & 0.923 & -0.146 & 0.003 \\
Diameter of eye & 0.725 & 0.192 & -0.197 \\
Preorbital distance & 0.615 & 0.096 & -0.450 \\
Postorbital distance & 0.789 & 0.074 & -0.231 \\
Predorsal fin distance & 0.906 & -0.197 & 0.038 \\
Dorsa fin height & 0.466 & 0.704 & 0.119 \\
Dorsal fin base & 0.763 & 0.089 & -0.040 \\
Ana fin height & 0.468 & 0.604 & 0.292 \\
Ana fin base length & 0.845 & -0.129 & 0.098 \\
Pectoral fin base length & 0.662 & -0.396 & 0.412 \\
\hline
\end{tabular}

Moderately high levels of polymorphism were displayed at all 6 microsatellite loci, which is not an unexpected result given the proposed higher rates of microsatellite mutation previously reported in marine fishes (O'Reilly et al. 2004). The reported significant departures from HWE support the presence of null alleles found in this study, which likely reveal issues regarding biased patterns of the disequilibrium. Moreover, the observed deviation from HWE and the relative high inbreeding values may be related to small sample sizes and/or individuals from the same progeny. The observed heterozygosity deficit related to the high $F_{\text {IS }}$ values suggests that saddled seabream do not mate randomly in the study area and that gene flow may be spatially restricted. However, the relatively limited gene flow and the high $F_{\mathrm{ST}}$ values among samples, along with the differentiation from HWE, might indicate a subdivision of the populations, suggesting sub-structuring of the species in the Aegean Sea.

This differentiated pattern in the Aegean Sea was previously reported in benthopelagic species; these species in the Aegean Sea seem to exhibit spatial differences with respect to their bentho-geographical distribution (Vafidis 2002, Kefalas et al. 2003, Voultsiadou 2005a). The authors argue that this dissimilarity of the north, central and south Aegean Sea conforms with the prolonged differences in species' genetic and morphological data in relation with geographical and physicochemical features of the area. The results of the present study further support such a hypothesis. The phenotypic univariate analysis indicated significant differences between the 8 populations for all morphometric characters. DA of morphometric characters further revealed a clear pattern of population structure segregating the saddled seabream individuals between the 3 major sub-areas of the Aegean Sea. The high significance of the morphometric analysis compared with the genetic analysis suggests that oceanographic factors (i.e. currents, cyclonic circulation, bathymetry) are a significant stressor for environmental plasticity.

According to the literature, barriers in the Aegean Sea coincide with strong oceanographic fronts of different nature as a result of a near-surface thermohaline circulation involving the low salinity outflow from the Black Sea in conjunction with the freshwater input of the continental shelf and the high salinity input from the south Aegean Sea (Poulos et al. 1997, Kourafalou et al. 2004). In addition, a basin-wide cyclonic circulation is taking place, resulting in subbasin scale gyres connected to the complex topography of the area (Nittis \& Perivoliotis 2002). Taking 
Table 5. Oblada melanura. Discriminant analysis output, showing the percentage of specimen classification in each sampled group (1 to 8). Overall classification $=66.5 \%$

\begin{tabular}{|c|c|c|c|c|c|c|c|c|}
\hline Population & 1 & 2 & 3 & 4 & 5 & 6 & 7 & 8 \\
\hline Volos & 75.1 & 4.2 & 0 & 5.7 & 0 & 15 & 0 & 0 \\
\hline Karystos & 20 & 70 & 0 & 0 & 0 & 0 & 10 & 0 \\
\hline Kavala & 0 & 0 & 31.3 & 31.2 & 0 & 12.5 & 12.5 & 12.5 \\
\hline Katerini & 10 & 5 & 15 & 35 & 0 & 15 & 20 & 0 \\
\hline Crete & 0 & 14.3 & 0 & 0 & 71.4 & 0 & 14.3 & 0 \\
\hline Trikeri & 10 & 0 & 0 & 10 & 0 & 80 & 0 & 0 \\
\hline Nikiti & 11.1 & 5.5 & 33.3 & 5.5 & 0 & 0 & 42.4 & 2.2 \\
\hline Paros & 0 & 0 & 0 & 0 & 66.6 & 0 & 0 & 33.4 \\
\hline Wilks' lambda & $F$ & & df & $\mathrm{p}$ & & & & \\
\hline 0.82288 & 5.60709 & & 7 & 0186 & & & & \\
\hline
\end{tabular}

them in turn, the conditions in the north Aegean contain extended shelf areas, 2 cyclonic and 1 anticyclonic system and a deep trench of $1500 \mathrm{~m}$, which present a physical geographical boundary to the central Aegean. The central Aegean forms extended deep areas, a cyclonic system and a boundary current along the continental shelf of an elongated island with Karystos at the southern end. The south Aegean contains many island complexes, a main cyclonic system and different water masses, and communicates with the western Mediterranean basin through Crete (for a review, see Olson et al. 2007). The different cyclone systems in the Aegean Sea contribute to different upwelling events and thus differentiated nutrientenriched water masses, suggesting differences in food resources and availability for biota (Theodorou 2004).

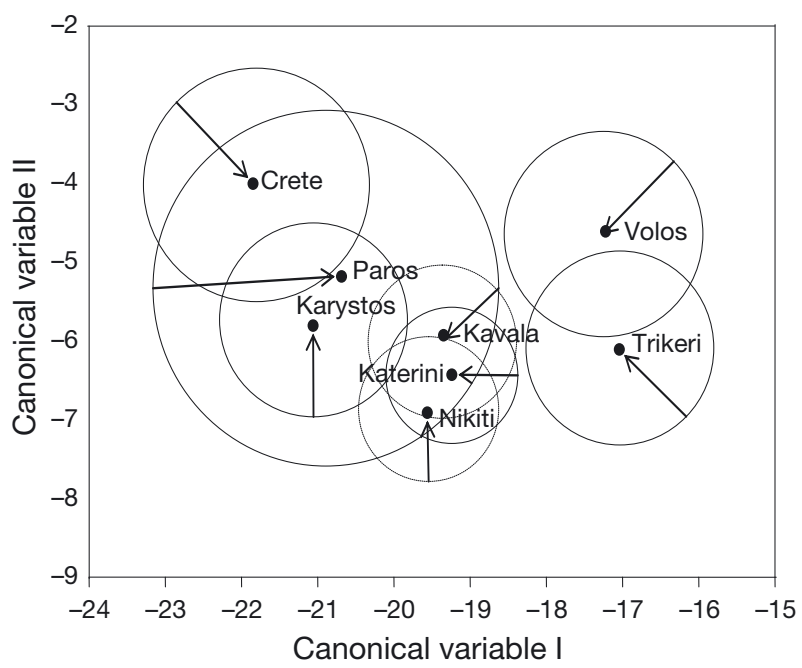

Fig. 6. Oblada melanura. Discriminant analysis plot of populations, where the 13 morphometric characters were used. Circles represent the percentage of the total of specimens correctly classified per population. Arrows indicate corresponding population
Biogeographically speaking, this documented cyclonic circulation is not only a food specialization habitat, and therefore boundary for saddled seabream dispersal potential, but also a transition zone with respect to ecological niches for many marine species (e.g. Voultsiadou 2005b). The saddled seabream is considered to have moderate pelagic larval duration with pelagic eggs and offshore larvae, suggesting a shorter pelagic duration than other marine species and an ultimately restricted gene flow due to tidal currents (Macpherson \& Raventos 2006, Galarza et al. 2009).

Despite the reported extensive phenotypic variability within and among populations, the fact is that specimens were collected on a differential seasonal basis during sampling. Therefore, it is probable that a large proportion of the intra-sample variation (i.e. various age groups) is the result of such heterogeneous phenotypic groups. To what degree these differences are the result of environmental conditions or genetic divergence remains to be determined, although the present data on microsatellite variability do confirm such differentiation. Within the limits of accuracy of the biometric experimental procedure, the characters of primary importance in distinguishing between the studied populations were those related to head and fin height dimensions; such characters explained approximately $70 \%$ of the total variance between the groups. Nonetheless, the DA classification accuracy for saddled seabream populations was somewhat lower and/or similar to values reported in the literature for other marine species (e.g. Alexander \& Breden 2004, Cabral et al. 2003, Mamuris et al. 1998, Karakousis et al. 1993, Claytor \& MacCrimmon 1988). However, one ought to bear in mind that such morphometric characteristics have a lower ability to discriminate populations than meristic (Karakousis et al. 1991) or even evolutionarily influenced characteristics. In any case, pairwise $F_{\mathrm{ST}}$ significances reflect the relative described differentiation: AMOVA was highly significant on 2 of the 3 hierarchical levels. Regarding the phenotypic analysis, results from both PCA and DA were highly significant.

Morphological variability among different geographical populations could be attributed to the variable genetic structure of populations and/or to different environmental conditions prevailing in each geographic area. Multivariate analyses can provide 
an efficient tool, along with genetic data interpretation, for stock definition, and thus would be useful for a conservation management project plan for Hellenic coastal resources. However, one cannot exclude the existence of possible undetected genetic structure of such populations, which could account for any detected morphological variation. Such findings are not unique, as some phenotypic adaptations are not dependent on genetic mutations. The novelties of some phenotypic adaptations are not immediately expressed in the species gene pool. The lack of differences in a study does not preclude the existence of stock differentiation, even when including the input of genetic forces, since this is a direct consequence of environmental adaptation (Schweigert 1991).

Historical processes producing isolation, or low connectivity in combination with potential bottlenecks in one or more subpopulations (although not detected in the present data set), could also lead to morphological and genetic differentiation. Moreover, the observed absence of HWE is maybe due to genetic drift (e.g. small sample size), and inbreeding is such a crucial process and is remarkably quite common for species favoring reproduction in the sea. As inbreeding is caused by mating of genetically related individuals (common in fishes), it results in increased homozygosity. Therefore, observed heterozygosities are likely to be lower than expected. Although this is not always the case, in the present study inbreeding within populations was high enough. Furthermore, intense fishing pressure, mainly overfishing, can also lead to potential bottlenecks and population divergence (see Perez-Ruzafa et al. 2006, Walsh et al. 2006, Baibai et al. 2012, Limborg et al. 2012), and thus apparent small populations often suffer from the loss of genetic diversity due to genetic drift and inbreeding effects. However, the present study assumed a structure between the 3 areas, which affects local effective population size and thus the level of inbreeding. Therefore, the considerable population structure revealed by the morphometric characteristics has the potential to influence the impact on fitness-related traits to a greater extent than may be expected from the genetic analysis. The Aegean Sea, being a semienclosed marginal basin of relatively small volume compared with the open sea, shows an amplified and very rapid response to climate change (Anagnostou et al. 2005). A large number of faunal studies in the area have succeeded in reconstructing the climatic conditions and documenting the general trend from the cold, glacial climate conditions of the late Pleistocene to the warm, interglacial conditions of the Holocene (see Cramp et al. 1988, Geraga et al. 2000).
Cyclonic circulation, current flows and life history seem to be the factors that best represent the nature of barriers to gene flow encountered across the Aegean Sea in saddled seabream populations. The revealed population structure and the species' geographic dispersal might be closely linked to the oceanographic features encountered in the studied area, and could act as a useful tool for the study of other physical processes, such as the abundance of plankton and nutrients, which regulate the ecological niche of bio-society in small scaled areas. Further analysis is required to address the demographic patterns of the saddled seabream, as well as the ecological aspects of plasticity in this species.

\section{LITERATURE CITED}

Adcock GJ, Bernal-Ramirez JH, Hauser L, Smith P, Carvalho GR (2000) Screening of DNA polymorphism in samples of archived scales from New Zealand snapper. J Fish Biol 56:1283-1287

Alexander HJ, Breden F (2004) Sexual isolation and extreme morphological divergence in the Cumaná guppy: a possible case of incipient speciation. J Evol Biol 17: $1238-1254$

Anagnostou C, Chronis G, Gogou A, Karageorgis AP and others (2005) Paleoceanography and paleocirculation of the Aegean Sea from the late glacial period to the present (20 000 years). In: Papathanasiou E, Zenetos A (eds) SoHelME, State of the Hellenic Marine Environment. HCMR Publ., Athens, p 21-23

Arculeo M, Lo Brutto S, Sirna-Terranova M, Maggioa T, Cannizzaro L, Parrinello N (2003) The stock genetic structure of two Sparidae species, Diplodus vulgaris and Lithognathus mormyrus, in the Mediterranean Sea. Fish Res 63:339-347

> Baibai T, Oukhattar L, Vasquez Q, Javier V, Mesfioui A, Rey-Mendez M, Soukri A (2012) First global approach: morphological and biological variability in a genetically homogeneous population of the European pilchard, Sardina pilchardus (Walbaum, 1792) in the North Atlantic coast. Rev Fish Biol Fish 22:63-80

Bauchot ML, Hureau CJ (1986) Sparidae. In: Whitehead PJP, Bauchot ML, Hureau JC, Nielsen J, Tortonese E (eds) Fishes of the North-eastern Atlantic and the Mediterranean. Vol II. UNESCO, Bungay, UK, pp. 883-907

Bauchot ML, Hureau JC (1990) Sparidae. In: Quero JC, Hureau JC, Karrer C, Post A, Saldanha L (eds) Check-list of the Fishes of the Eastern Tropical Atlantic, Clofeta II. UNESCO, Paris, p 790-812

Bauchot ML, Hureau JC, Miquel JC (1981) Sparidae. In: Fischer WG, Bianchi G, Scott WB (eds) FAO species identification sheets for fishery purposes: Eastern Central Atlantic; fishing areas 34, 47 (in part). Canada funds-in-Trust, Ottawa

Beerli P, Palczewski M (2010) Unified framework to evaluate panmixia and migration direction among multiple sampling locations. Genetics 185:313-326

Bekkevold D, Andre C, Dahlgren TG, Clausen LA and others (2005) Environmental correlates of population differentiation in Atlantic herring. Evolution 59:2656-2668

Bohonak AJ (1999) Dispersal, gene flow, and population structure. Q Rev Biol 74:21-45 
Bohonak AJ (2002) IBD (isolation by distance): a program for analyses of isolation by distance. J Hered 93:153-154

Brassel KE, Reif D (1979) A procedure to generate Thiessen polygons. Geogr Anal 325:31-36

$>$ Brown RC, Tsalavouta M, Terzoglou V, Magoulas A, McAndrew BJ (2005) Additional microsatellites for Sparus aurata and cross-species amplification within the Sparidae family. Mol Ecol Notes 5:605-607

> Cabral HN, Marques JF, Rego AL, Catarino AI, Figueiredo J, Garcia J (2003) Genetic and morphological variation of Synaptura lusitanica (Capello, 1868) along the Portuguese coast. J Sea Res 50:167-175

Chapuis MP, Estoup A (2007) Microsatellite null alleles and estimation of population differentiation. Mol Biol Evol 24:621-631

> Claytor RR, MacCrimmon HR (1988) Morphometric and meristic variability among North American Atlantic salmon (Salmo salar). Can J Zool 66:310-317

Coll M, Piroddi C, Steenbeek J, Kaschner K and others (2010) The biodiversity of the Mediterranean Sea: estimates, patterns, and threats. PLoS ONE 5:e11842

Cramp A, Collins M, West R (1988) Late PleistoceneHolocene sedimentation in the NW Aegean Sea: a palaeoclimatic palaeoceanographic reconstruction. Palaeogeogr Palaeoclimatol Palaeoecol 68:61-77

Excoffier L, Lischer HEL (2010) Arlequin suite ver 3.5: A new series of programs to perform population genetics analyses under Linux and Windows. Mol Ecol Res 10: 564-567

Falush D, Stephens M, Pritchard JK (2003b) Inference of population structure using multilocus genotype data: linked loci and correlated allele frequencies. Genetics 164:1567-1587

Galarza JA, Carreras-Carbonell J, Macpherson E, Pascual M, Roques S, Turnere GF, Ricod C (2009) The influence of oceanographic fronts and early-life-history traits on connectivity among littoral fish species. Proc Natl Acad Sci USA 106:1473-1478

Geraga M, Tsaila-Monopolis S, Ioakeim C, Papatheodorou G, Ferentinos G (2000) Evaluation of palaeoenvironmental changes during the last 18000 years in the Myrtoon basin, SW Aegean Sea. Palaeogeogr Palaeoclimatol Palaeoecol 156:1-17

González-Wangüemert M, Froufe E, Pérez-Ruzafa A, Alexandrino P (2011) Phylogeographical history of the white seabream Diplodus sargus (Sparidae): implications for insularity. Mar Biol Res 7:250-260

Goudet J (2001) FSTAT, a program to estimate and test gene diversities and fixation indices (version 2.9.3); http://www. unil.ch/izea/softwares/Fstat.html

Hoelzel AR (2009) Evolution of population structure in marine mammals. In: Bertorelle G, Bruford MW, Hauffe HC, Rizzoli A, Vernesi C (eds) Population genetics for animal conservation. Cambridge University Press, New York, NY, p 294-318

Hoelzel AR, Hey J, Dahlheim ME, Nicholson C, Burkanov V, Black N (2007) Evolution of population structure in a highly social top predator, the killer whale. Mol Biol Evol 24:1407-1415

Hubbs C, Lagler K (1967) Fishes of the Great Lakes Region. University of Michigan Press, Ann Arbor, MI

Jardas I (1996) Jadransha ihtiofanna. Skolsha Knjiga, Zagreb

> Jørgensen HBH, Hansen MM, Bekkevold D, Ruzzante DE, Loeschcke V (2005) Marine landscapes and population genetic structure of herring (Clupea harengus L.) in the Baltic Sea. Mol Ecol 14:3219-3234

Karakousis Y, Triantaphyllidis C, Economidis P (1991) Mor- phological variability among seven Greek populations of brown trout (Salmo trutta). J Fish Biol 38:807-817

Karakousis Y, Peios C, Economidis P, Triantaphyllidis C (1993) Multivariate analysis of the morphological variability among Barbus peloponnesius (Cyprinidae) populations from Greece and two populations of B. meridionalis meridionalis and $B$. meridionalis petenyi. Cybium 17:229-240

Kefalas E, Tsirtsis G, Castritsi-Catharios I (2003) Distribution and ecology of Demospongiae from the circalittoral of the islands of the Aegean Sea (Eastern Mediterranean). Hydrobiologia 499:125-134

Kelly RP, Palumbi SR (2010) Genetic structure among 50 species of the Northeastern Pacific rocky intertidal community. PLoS ONE 5:e8594

Klaoudatos S, Pouli A, Katsoris T, Conides A (1997) Study of hermaphroditism of new euryhaline finfish species candidate for aquaculture. Technical report 1469 PENED 94, NVMR/University of Athens

Kourafalou VH, Savvidis YG, Koutitas CG, Krestenitis YN (2004) Modelling studies on the processes that influence matter transfer on the Gulf of Thermaikos (NW Aegean Sea). Cont Shelf Res 24:203-222

Lenfant P, Olive C (1998) Changements gradueles du régime alimentarie des juvéniles d'Oblade (Oblada melanura, Sparidae) lors du recrutement. Cybium 22:203-210

Limborg MT, Hanel R, Debes PV, Ring AK, André C, Tsigenopoulos CS, Bekkevold D (2012) Imprints from genetic drift and mutation imply relative divergence times across marine transition zones in a pan-European small pelagic fish (Sprattus sprattus). Heredity 109: 96-107

> Luikart G, Allendorf FW, Cornuet JM, Sherwin WB (1998) Distortion of allele frequency distributions provides a test for recent population bottlenecks. J Hered 89:238-247

> Macpherson E, Raventos N (2006) Relationship between pelagic larval duration and geographic distribution of Mediterranean littoral fishes. Mar Ecol Prog Ser 327: $257-265$

- Magoulas A, Castilho R, Caetano S, Marcato S, Patarnello T (2006) Mitochondrial DNA reveals a mosaic pattern of phylogeographical structure in Atlantic and Mediterranean populations of anchovy (Engraulis encrasicolus). Mol Phylogenet Evol 39:734-746

> Mamuris Z, Apostolidis AP, Panagiotaki P, Theodorou AJ, Triantaphyllidis C (1998) Morphological variation between red mullet populations in Greece. J Fish Biol 52: $107-117$

> Manni F, Guérard E, Heyer E (2004) Geographic patterns of (genetic, morphologic, linguistic) variation: how barriers can be detected by 'Monmonier's algorithm'. Hum Biol 76:173-190

McCusker MR, Bentzen P (2010) Historical influences dominate the population genetic structure of a sedentary marine fish, Atlantic wolffish (Anarhichas lupus), across the North Atlantic Ocean. Mol Ecol 19:4228-4241

Monmonier M (1973) Maximum-difference barriers: an alternative numerical regionalization method. Geogr Anal 3: 245-261

Nittis K, Perivoliotis L (2002) Circulation and characteristics of the North Aegean Sea: a contribution from real-time buoy measurements. Medit Mar Sci 3:21-31

> Olson DB, Kourafalou VH, Johns WE, Samuels G, Veneziani M (2007) Aegean surface circulation from a satellitetracked drifter array. J Phys Oceanogr 37:1898-1917

> O'Reilly PT, Canino MF, Bailey KM, Bentzen P (2004) Inverse relationship between $F_{\mathrm{ST}}$ and microsatellite poly- 
morphism in the marine fish, walleye pollock (Theragra chalcogramma): implications for resolving weak population structure. Mol Ecol 13:1799-1814

Palma J, Andrade JP (2004) Morphological study of Pagrus pagrus, Pagellus bogaraveo, and Dentex dentex (Sparidae) in the Eastern Mediterranean Sea. J Mar Biol Assoc UK 84:449-454

Palumbi S (1994) Genetic divergence, reproductive isolation, and marine speciation. Annu Rev Ecol Syst 25:547-572

Perez-Ruzafa A, Gonzalez-Wanguemert M, Lenfant P, Marcos C, Garcia-Charton JA (2006) Effects of fishing protection on the genetic structure of fish populations. Biol Conserv 129:244-255

Pilot M, Dahlheim ME, Hoelzel AR (2010) Social cohesion among kin, gene flow without dispersal and the evolution of population genetic structure in the killer whale (Orcinus orca). J Evol Biol 23:20-31

Pinera JA, Blanco G, Vazquez E, Sanchez JA (2007) Genetic diversity of blackspot seabream (Pagellus bogaraveo) populations of Spanish Coasts: a preliminary study. Mar Biol 151:2153-2158

Piry S, Luikart G, Cornuet JM (1999) Bottleneck: a computer program for detecting recent reductions in the effective size using allele frequency data. J Hered 90:502-503

> Poulos SE, Drakopoulos PG, Collins MB (1997) Seasonal variability in sea surface oceanographic conditions in the Aegean Sea (eastern Mediterranean): an overview. J Mar Syst 13:225-244

Pritchard JK, Stephens M, Donnelly P (2000a) Inference of population structure using multilocus genotype data. Genetics 155:945-959

Raymond M, Rousset F (1995) GENEPOP (version 1.2) Population genetics software for exact tests and ecumenicism. J Hered 86:248-249

Reist J (1985) An empirical evaluation of several Univariate methods that adjust for size variation in morphometric data. Can J Zool 63:1429-1439

Rice WR (1989) Analyzing tables of statistical tests. Evolution 43:223-225

Rolland JL, Bonhomme F, Lagardère F, Hassan M, Guinand B (2007) Population structure of the common sole (Solea solea) in the Northeastern Atlantic and the Mediterranean Sea: revisiting the divide with EPIC markers. Mar Biol 151:327-341

Roques S, Galarza JA, McPherson E, Turner GF, Rico C (2007) Isolation and characterization of nine polymorphic microsatellite markers in the two-banded sea bream (Diplodus vulgaris) and cross-species amplification in the white sea bream (Diplodus sargus) and the saddled bream (Oblada melanura). Molec Ecol Notes 7(4):661-663

Roughgarden J (1972) Evolution of niche width. Am Nat 106:683-718

Roughgarden J (1974) Niche width: biogeographical patterns among Anolis lizard populations. Am Nat 108:429-442

Rousset F (1997) Genetic differentiation and estimation of gene flow from $F$-statistics under isolation by distance. Genetics 145:1219-1228

Salmenkova EA (2011) New view on the population genetic

Editorial responsibility: Francesco Patti,

Naples, Italy structure of marine fish. Genetika 47:1440-1450

Sambrook J, Russel DW (2001) Molecular cloning: a laboratory manual, 3rd edn. Cold Spring Harbor Laboratory Press, Cold Spring Harbor, NY

Schaefer KM (1989) Morphometric analysis of yellowfin tuna Thunnus albacares from the Pacific Ocean. InterAm Trop Tuna Comm Bull 19:389-427

Schweigert JF (1991) Multivariate description of Pacific herring (Clupea harengus pallasi) stocks from size and age information. Can J Fish Aquat Sci 48:2365-2376

Siokou-Frangou I, Bianchi M, Christaki U, Christou ED and others (2002) Carbon flow in the planktonic food web along a gradient of oligotrophy in the Aegean Sea (Mediterranean sea). J Mar Syst 33-34:335-353

Theodorou A (2004) Oceanography: an introduction to marine environment. Stamoulis, Athens

Thorpe RS (1987) Geographic variation: a synthesis of cause, data pattern and congruence in relation to subspecies, multivariate analysis and phylogenies. Boll Zool 54:3-11

Toonen RJ, Hughes S (2001) Increased throughput for fragment analysis on ABI Prism 377 Automated Sequencer using a membrane comb and STRand Software. Biotechniques 31:1320-1324

Vafidis D (2002) Biogeography of the Anthozoa coelenterate fauna of the Mediterranean Sea. 9th Int Congr Zoogeography and Ecology of Greece and adjacent regions (ICZEGAR), Thessaloniki, 22-25 May, Abstracts, p 159

van Oosterhout C, Hutchinson WF, Wills DPM, Shipley P (2004) Microchecker: software for identifying and correcting genotyping errors in microsatellite data. Mol Ecol Notes 4:535-538

Viñas J, Bremer JA, Pla C (2004) Phylogeography of the Atlantic bonito (Sarda sarda) in the northern Mediterranean: the combined effects of historical vicariance, population expansion, secondary invasion, and isolation by distance. Mol Phylogenet Evol 33:32-42

Voronoï MG (1908) Nouvelles application des paramètres continus à la théorie des formes quadratiques, deuxième mémoire, recherche sur le paralléloedres primitifs. J Reine Angew Math 134:198-207

Voultsiadou E (2005a) Sponge diversity in the Aegean Sea: checklist and new information. Ital J Zool 72:53-64

> Voultsiadou E (2005b) Demosponge distribution in the eastern Mediterranean: a NW-SE gradient. Helgol Mar Res 59:237-251

Walsh MR, Munch SB, Chiba S, Conover DO (2006) Maladaptive changes in multiple traits caused by fishing: impediments to population recovery. Ecol Lett 9:142-148

Weir BS, Cockerham CC (1984) Estimating F-statistics for the analysis of population structure. Evolution 38: 1358-1370

Zar JH (1984) Biostatistical analysis. Prentice Hall, Upper Saddle River, NJ

Zulliger DE, Tanner S, Ruch M, Ribi G (2009) Genetic structure of the high dispersal Atlanto-Mediterreanean sea star Astropecten aranciacus revealed by mitochondrial DNA sequences and microsatellite loci. Mar Biol 156: $597-610$

Submitted: July 24, 2012; Accepted: December 14, 2012 Proofs received from author(s): February 21, 2013 